\title{
Dishevelled stablisation at the cilium by RPGRIP1L is essential for planar cell polarity
}

\author{
S Schneider-Maunoury ${ }^{1 *}$, A Mahuzier ${ }^{1}$, HM Gaudé2 ${ }^{2}$ I Anselme ${ }^{1}$, F Silbermann², M Leroux-Berger ${ }^{1}$, \\ M Montcouquiol $^{3}$, S Saunier ${ }^{2}$, C Vesque ${ }^{1}$
}

From First International Cilia in Development and Disease Scientific Conference (2012) London, UK. 16-18 May 2012

Cilia are involved in planar polarity in different systems but the mechanisms by which they influence the polarization process are unclear [1]. In order to clarify this issue, we investigated the function of the ciliary gene Rpgrip1l (Ftm/NPHP8/MKS5) in the mammalian cochlear sensory epithelium and in the zebrafish floor plate. We and others have previously shown that mutations in the human RPGRIP1L gene cause Meckel and Joubert type B syndromes [2]. The Rpgrip1l protein is localised at the ciliary transition zone and is required for transduction of the $\mathrm{Hh} /$ Gli pathway [3]. Our recent work has shown that Rpgrip1l patterns the telencephalon via the regulation of Gli3 proteolytic cleavage [4]. Here we show that in both the mammalian cochlear sensory epithelium and the zebrafish floor plate, Rpgrip1l is required for correct positioning of the basal body along the planar polarity axis. Our results strongly suggest that Rpgrip1l is essential for stabilizing the adaptor protein dishevelled at the basal body and/or cilium. Finally, we demonstrate that, in the zebrafish floor plate, the function of Rpgrip1l in basal body positioning is mediated by dishevelled. We propose that Rpgrip1l participates in a protein complex required for stabilizing dishevelled at the cilium, and that this stabilization is essential for asymmetric localization of the basal body along the planar polarity axis.

\section{Author details \\ 'CNRS UMR7622, Université Pierre et Marie Curie, France. ${ }^{2}$ INSERM U983, Hôpital Necker-Enfants Malades, France. ${ }^{3}$ INSERM U862, Université Bordeaux 2, France.}

Published: 16 November 2012

\section{References}

1. Wallingford, Mitchell : Genes Dev 2011, 25:201-13.

\footnotetext{
* Correspondence: sylvie.schneider-maunoury@snv.jussieu.fr

'CNRS UMR7622, Université Pierre et Marie Curie, France

Full list of author information is available at the end of the article
}

2. Delous, et al: Nat Genet 2007, 39:875-81.

Vierkotten, et al: Development 2007, 134:2569-77

4. Besse, et al: Development 2011, 138:2079-88.

doi:10.1186/2046-2530-1-S1-O21

Cite this article as: Schneider-Maunoury et al.: Dishevelled stablisation at the cilium by RPGRIP1L is essential for planar cell polarity. Cilia 2012 1(Suppl 1):021.
Submit your next manuscript to BioMed Central and take full advantage of:

- Convenient online submission

- Thorough peer review

- No space constraints or color figure charges

- Immediate publication on acceptance

- Inclusion in PubMed, CAS, Scopus and Google Scholar

- Research which is freely available for redistribution

\section{() Biomed Central}

C Biomed Central

@ 2012 Schneider-Maunoury et al; licensee BioMed Central Ltd. This is an Open Access article distributed under the terms of the Creative Commons Attribution License (http://creativecommons.org/licenses/by/2.0), which permits unrestricted use, distribution, and reproduction in any medium, provided the original work is properly cited. 